\title{
Medical theories on the cause of death in crucifixion
}

\author{
Matthew W Maslen Piers D Mitchell
}

J R Soc Med 2006;99:185-188

\section{INTRODUCTION}

Crucifixion may be defined as a method of execution by which a person is hanged, usually by their arms, from a cross or similar structure until dead. It has been used in many parts of the world and in many time periods; but is perhaps best known today as a cruel method of social control and punishment in the Roman Empire around 2000 years ago ${ }^{1}$ (pp 22-3). In modern times, the medical profession has shown considerable interest in crucifixion. The typical aim of articles by this group has been to determine how crucified individuals actually died; and they often focus on the case of Jesus of Nazareth. Since Stroud's book of $1847,{ }^{2}$ at least 10 different theories have been proposed (Table 1), and many more articles have been published suggesting various combinations of these theories. The 10 examples referenced in Table 1 have been chosen merely as representing the wide difference of opinion in the published literature: it is not an exhaustive list of all articles published on the subject. The postulated causes of death include cardiovascular, respiratory, metabolic, and psychological pathology. Some authors have even argued that in a limited proportion of cases the victim only appeared to die, and recovered consciousness once brought down from the cross.

When a large number of theories are proposed for a problem in any scientific discipline, this often demonstrates that there is no clear evidence indicating the answer. Here we investigate why there are over 10 completely different theories described in the medical literature.

\section{METHOD}

An extensive search for publications on crucifixion was undertaken. These were divided into three groups by main profession of the author, be they physicians, archaeologists or historians. Over 40 articles and books by physicians that discussed the medical causes of death in crucifixion were studied. The publications by historians and archaeologists were used to provide background information on crucifixion. Early printed editions of Latin texts dating from the Roman period, held in the British Library, were

Faculty of Medicine, Charing Cross Campus, Imperial College London, London W6 8RP, UK

Correspondence to: Dr Piers Mitchell

E-mail: piers.mitchell@imperial.ac.uk consulted for passages describing crucifixion. The replica model of the only archaeological case of crucifixion yet found (from Giv'at ha-Mivtar) was studied during a visit to Jerusalem. This case was discussed in detail with an osteoarchaeologist in Israel who examined the original bones prior to their reburial.

A summary of the available historical, archaeological and re-enactment evidence was constructed. This was compared with the evidence discussed in each of the publications by medical authors, in order to determine the breadth of information consulted prior to the proposal of their hypothesis as to how crucifixion victims died.

\section{HISTORICAL EVIDENCE}

Written evidence for the details of crucifixion has been limited to eyewitness accounts and other related written texts. No Roman period instructions for those performing crucifixion have been preserved as far as we are aware. The most detailed accounts of any one particular crucifixion are the biblical passages covering the death of Jesus of Nazareth; but we should not assume that this was by any means representative of all crucifixions. Indeed, the precise details may well have varied between regions, evolved over time, or even depending upon the social status of the victim and the crime he allegedly committed. Flavius Josephus (37c.100CE) wrote of the hundreds of Jewish prisoners crucified at Jerusalem in $70 \mathrm{CE}$, during an uprising against the Romans.

'They were first whipped and then tormented with all sorts of tortures, before they died, and were crucified before the wall of the city . . . the soldiers, out of wrath and hatred they bore the Jews, nailed those they caught to the crosses in different postures, by way of jest'. ${ }^{3}$

Lucius Anneus Seneca (4BCE-65CE) recorded another mass crucifixion and noted:

'I see crosses there, not just of one kind but made in many different ways: some have their victims with their head down to the ground, some impale their private parts, others stretch out their arms'. ${ }^{4}$

In Roman times a common starting point was to be whipped across the back, buttocks and legs with a flagrum. 
Table 1 A representative selection of medical hypotheses for the cause of death of Jesus, or crucifixion in general

\begin{tabular}{lll}
\hline Cause of death & Background of author & Reference \\
\hline Cardiac rupture & Physician & Stroud 1847 (Ref 2) \\
Heart failure & Physician & Davis 1965 (Ref 15) \\
Hypovolaemic shock & Forensic pathologist & Zugibe 2005 (Ref 12) \\
Syncope & Surgeon & LeBec 1925 (Ref 16) \\
Acidosis & Physician & Wijffels 2000 (Ref 17) \\
Asphyxia & Surgeon & Barbet 1963 (Ref 18) \\
Arrhythmia plus asphyxia & Pathologist & Edwards 1986 (Ref 19) \\
Pulmonary embolism & Haematologist & Brenner 2005 (Ref 20) \\
Voluntary surrender of life & Physician & Wilkinson 1972 (Ref 21) \\
Didn't actually die & Physician & Lloyd-Davies 1991 (Ref 22) \\
\hline
\end{tabular}

This was a short whip with sharp objects interweaved into the thongs. The victim was then often obliged to carry part of their cross to the place of execution, outside the city walls. The weight of this would obviously vary depending upon the region and the type of wood used. Once at the place of crucifixion, the hands and feet of the prisoner were fixed to the cross with either nails or cords, and the cross erected in any one of a range of orientations. If crucified head up, the victim's weight may also have been supported on a small seat. This was believed to prolong the time it took a man to die. Victims in the head up position could spend several days on the cross before they died. One technique used by the Romans to hasten death was to break the legs below the knee with a blunt instrument ${ }^{1}$ (p. 25). Modern interpretation in the medical literature as to how this might work includes blood loss from the fracture site or respiratory failure from fat embolism. In those positioned head up then respiratory failure might also ensue as a consequence of the inability to inflate the chest sufficiently, since the legs could no longer be used to support the weight of the body. However, it is unknown which of these three widely stated hypotheses is correct, since crucifixion is not employed as a modern legal method of execution.

Analysis of the clinical literature suggests that there has been suboptimal use of these historical sources in post publications. Over 40 such articles have been reviewed for this study, although only a proportion of these have specifically been quoted in the reference list as they highlight particular points. The vast majority of articles do not refer to texts in the original languages that describe the details of crucifixion, which are mostly in Latin and Greek. At best there is occasional reference to the few Roman period texts that have been published in English translation. ${ }^{5,6}$ However, most papers do not even discuss the translations of these texts, but chose to quote previous information. ${ }^{7,8}$ In some cases the result is a series of misquotes that bear limited resemblance to the actual surviving evidence.

\section{ARCHAEOLOGICAL EVIDENCE}

There has been just one archaeological case of crucifixion published to our knowledge. Cases are rare, as most crucified people were not formally buried, but left on a rubbish dump to be eaten by wild dogs and hyenas. The one case we do have was a young Jewish man buried during the Roman Period, in a tomb near Giv'at ha-Mivtar in Israel. ${ }^{9}$ The inscription on the ossuary suggests his name was probably Yehohanan ben Hagkol. The skeletal remains were only available for study for a few weeks before being given a Jewish burial, although a model of this calcaneus and nail have been exhibited in the Israel Museum in Jerusalem. The excavated remains were fragmentary and incomplete, but were unmistakably a case of crucifixion. The initial osteoarchaeological interpretation of the remains ${ }^{10}$ was of poor quality, and somewhat misleading. A much more expert analysis of these remains was published in 1985 by Zias and Sekeles. ${ }^{11}$ They described how an $11.5 \mathrm{~cm}$ iron nail had been hammered through the body of the right calcaneus from lateral to medial, and was still in situ (Figure 1). The tip of the nail was bent, suggesting that during its insertion it had perhaps met a hard knot of wood or pre-existing nail left from an earlier crucifixion. The remains of a flat piece of olive wood were found to be located between the lateral aspect of the calcaneus and the head of the nail. Its use may have been to prevent the crucifixion victim freeing his foot by forcing it laterally over the head of the nail. It seems that, at least in this case, the heels were nailed to the sides of the cross. There was no evidence for nail insertion through the bones of the wrist or forearm, although this is widely stated in medical articles. The appearance of the 


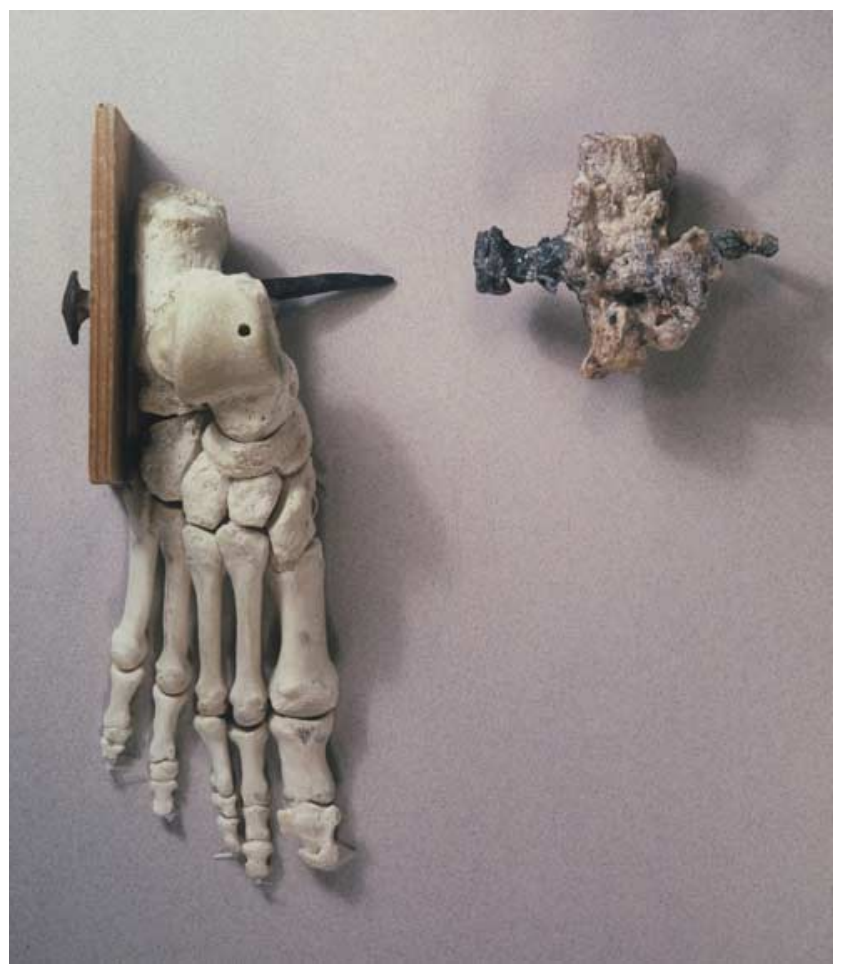

Figure 1 Calcaneus transfixed by an iron nail, from a first century AD Jewish tomb at Giv'at ha-Mivtar. Excavated bone on the right, model reconstruction on left. [Reproduced with the kind permission of Dr Joe Zias, Israel.] (In colour online.)

tibial fragments was suggestive of post mortem damage due to the decomposition process, and not ante mortem fractures to hasten death. However, several medical articles incorrectly state that they were ante mortem. We also have no idea as to whether this particular victim was positioned head up, head down, or in any other orientation.

Every carving of Jesus' crucifixion that we have ever seen in Catholic or Protestant churches have a nail passing through both feet from front to back. This religious stereotype has influenced the views of many researchers over the years. However, there is no evidence that crucifixion was actually carried out in this way in classical times.

\section{EVIDENCE FROM RE-ENACTMENT}

Over the years a number of researchers have tried to test both the physiology and the symptomatology of crucifixion. Zugibe has been the most recent, and the most thorough, with his humane experimental recreation of certain aspects of crucifixion. ${ }^{12}$ The volunteers were attached to the cross in a safe and temporary way, were carefully monitored, and the study terminated at the time of their request. The fact that none of the re-enactment research has actually crucified people means that these studies have only limited relevance to genuine cases. The absence of whipping, carrying a heavy cross, being nailed to it, the dehydration from water deprivation and hot sun, and the anxiety of their imminent death might all have resulted in somewhat different findings in the modern groups and crucifixion victims 2000 years ago. Furthermore, re-enacted crucifixions have typically placed their volunteers in the head up position displayed in Christian churches, and not in the wide variety of positions recorded in the written records from Roman times.

Zugibe attached the hands of his volunteers to a cross with leather gloves. The legs were placed with the knees and hips flexed and with the plantar surface of the feet flush with the anterior aspect of the cross upright. They were attached to the upright using a belt that ran over the dorsum of the feet. This choice of foot position seems to have been influenced by images in churches, but is at odds with the archaeological evidence and, to our knowledge, is not supported by historical evidence either. Zugibe's aim was to establish the cause of death of Jesus of Nazareth, and he tested many physiological variables in a systematic manner. He concluded that hypovolaemic shock caused Jesus' death, and the asphyxiation theory had been overwhelmingly disproved $^{12}$ (p. 121). However, the conclusion was not based on any positive evidence for the shock theory (which was not tested), but rather upon negative evidence for the asphyxiation theory. It seems that none of the volunteers suffered significant difficulty breathing while on the replica cross. However, the longest time any were left on the cross seems to have been limited, on account of the physical discomfort of being on the cross. Since it was extremely rare for anyone in Roman times to die on a cross within the first few hours, it could be argued that the time scale of the study cannot disprove the asphyxiation theory. Furthermore, much of Zugibe's arguments are based on evidence from the Turin Shroud. This appears to be a medieval forgery dating from between 1260 and 1390CE, since fibres have been radiocarbon dated by three separate laboratories. ${ }^{13}$ While some claim that the carbon date merely reflects the date of a medieval repair to the material, ${ }^{14}$ we would argue that there is still no firm evidence to suggest that the shroud of Turin can be used as part of an impartial scientific study.

\section{DISCUSSION}

We have highlighted 10 theories put forward by medical practitioners who have investigated the medical cause of death by crucifixion. They include forensic pathologists, physicians, and surgeons with outstanding pedigrees from around the world. At first glance, their medical arguments appear plausible. However, our principal finding is that on more detailed examination most of these hypotheses regarding crucifixion are unsubstantiated by the available data. The evidence for crucifixion that we have discussed 
here includes archaeological, historical, and re-enactment. Very few of the past medical publications in the field show awareness of this full range of evidence. Many are limited to those few written sources that have been translated into English. The arguments of these earlier papers often rely on the Turin Shroud for evidence, despite the fact that there is fair evidence to suggest that it is a forgery. Many articles just quote earlier medical publications, without discussing original sources themselves. The archaeological evidence, namely the crucified man from Giv'at ha-Mivtar, is often ignored. This is a crucial point, as it is arguably the most important and reliable evidence for crucifixion that exists. Very few papers show any sign of input from historians or osteoarchaeologists in order to expand upon the medical expertise of the authors.

The strengths of this study are that it provides an impartial assessment of past work in the field. It gives credit to good published research, but highlights major problems where they appear. The authors possess the necessary linguistic, medical and archaeological skills to undertake such a study. We have not engaged in humane re-enactment research ourselves, so have no preferred cause of death that we wish to champion. The weaknesses of the study perhaps include the fact that, since we have not performed humane re-enactment research ourselves, it could be argued we are in a less knowledgeable position from which to comment on the usefulness of the re-enactment research that has been undertaken. Neither do we claim to have first hand experience of the challenges and difficulties associated with developing a humane and ethical research protocol.

Our conclusion is that, at present, there is insufficient evidence to safely state exactly how people did die from crucifixion in Roman times. It is quite likely that different individuals died from different physiological causes, and we would expect that the orientation in which they were crucified would be crucial in this respect. Until new archaeological or textual evidence comes to light then it is only through more realistic humane re-enactment research that we may move closer to an answer. However, the difficulty in creating a research method that is more realistic, while ensuring that it remains humane, ethical and painless may be quite a challenge. Most importantly, future publication of articles in the medical literature should be restricted to those that consider the full range of historical and archaeological evidence. This may well require a collaborative team approach including historians and archaeologists as well as physicians.
Acknowledgments We are most grateful to Dr Joe Zias (formerly Curator for Physical Anthropology, Israel Antiquities Authority) for discussing the archaeological evidence with us, and for allowing us to reproduce his images of the calcaneus and crucifixion nail.

Competing interests None declared.

\section{REFERENCES}

1 Hengel M. Crucifixion in the Ancient World, and the Folly of the Message of the Cross, transl Bowden J. London: SCM Press, 1986

2 Stroud W. A Treatise on the Physical Cause of the Death of Christ. London: Hamilton \& Adams, 1847

3 Josephus F. In: Rufinus T, ed. De Bello Iudaico. Lugduni: Sebastian Germa, 1528:323-4

4 Seneca LA. In: Michaelis HC, ed. De Consolatione ad Marciam. Harlem: Vincent Loosjes, 1840

5 Retief FP, Cilliers L. The history and pathology of crucifixion. S Afr Med J 2003;93:938-41

6 Holoubek JE, Holoubek AB. Execution by crucifixion: history, methods and cause of death. J Med 1995;26:1-16

7 DeBoer SL, Maddow CL. Emergency care of the crucifixion victim. Accid Emerg Nurs 2002;10:235-9

8 Ball DA. The crucifixion and death of a man called Jesus. J Miss State Med Assoc 1989;30:77-83

9 Tzaferis V. Jewish tombs at and near Giv'at ha-Mivtar, Jerusalem. Israel Explor J 1970;20:18-32

10 Haas N. Anthropological observations on the skeletal remains from Giv'at ha-Mivtar. Israel Explor J 1970;20:38-59

11 Zias J, Sekeles E. The crucified man from Giv'at ha-Mivtar: a reappraisal. Israel Explor J 1985;35:22-7

12 Zugibe FT. The Crucifixion of Jesus: a Forensic Enquiry. New York: M Evans, 2005

13 Damon PE, Donahue DJ, Gore BH, et al. Radiocarbon dating of the Shroud of Turin. Nature 1989;337:611-15

14 Bollone PB. The Shroud Under the Microscope: Forensic Examination, transl Neame A. High Wycombe: St Pauls, 1998

15 Davis CT. The crucifixion of Jesus: the passion of Christ from a medical point of view. Ariz Med 1965;22:183-7

16 LeBec A. The death of the cross: a physiological study of the passion of Our Lord Jesus Christ. Catholic Med Guardian 1925;3:126-32

17 Wijffels F. Death on the cross: did the Turin Shroud once envelop a crucified body? Br Soc Turin Shroud Newsl 2000;52(3)

18 Barbet P. A Doctor at Calvary: the Passion of Our Lord Jesus Christ as Described by a Surgeon, transl The Earl of Wicklow. New York: Image Books, 1963:87

19 Edwards WD, Gabel WJ, Hosmer FE. On the physical cause of death of Jesus Christ. JAMA 1986;255:1455-63

20 Brenner B. Did Jesus Christ die of pulmonary embolism? J Thromb Haemost 2005;3:1-2

21 Wilkinson J. The physical cause of the death of Christ. Expository Times 1972;83:104-7

22 Lloyd-Davies M, Lloyd-Davies TA. Resurrection or resuscitation? J Roy Coll Phys Lond 1991;25:167-70 